\title{
A Date With Nature
}

By Ray Peterson

R.R. 2 Tofield, Alberta

There is a wealth of enjoyment in rambling through the woods and pasture. You can pass through a certain area a dozen times a week, yet Mother Nature; with superb showmanship, always has something of interest to display.

A few days ago, using a recent thunder shower as an excuse to skip work, I set off, swinging my usual equipment, a pan for mushrooms and a container for berries.

Clumps of wild roses, pink and fragrant, were common along the way. One cluster, as though standing on tip toes to twine wreaths in a willow bush, was over seven feet tall. This year's record rainfall and late spring has upset many schedules. The roses, as if trying to make up for a six week lag, have been amazingly prolific and showy.

A Red-tailed Hawk burst from a grove of aspen. In noisy pursuit darted an alliance of feathered fighters, a crow and a blackbird. I wonder if the blackbird called for reinforcements to harass his ally after the hawk had been banished.

Pushing through the leat mold alongside a willow crown, were a large number of Inky Caps. These mushrooms, members of the Coprinus tribe, are always welcome at our table. Another find was a large, purplish capped fungus with yellow gills and a white stem, Russula alutacea. This is a tasty plant with a distinctive flavor that makes it one of our favorites.

Lavish mantles of Fleabane daisies brightened the meadowlands. In moist, shady spots where woods and (Continued on Page 7)

\section{Summer Treasure}

Elizabeth Cruickshank, Regina

This summer we "travelled the roads not meant for hurry, but for heart's content." No road failed to yield delight.

Snows coming, after Spring's green, brought many birds within view of our kitchen window. We wished we could feed all the migrants suddenly deprived of food.

In the valley, Baltimores, in their brilliant plumage and large numbers, looked so incongruous. In the same field a cow was nudging and licking a brown bundle in the snow. Finally the bundle moved and a wee calf responded to the young mother's urging. Cows, dumb?

Where beavers had built a dam that had stood the stresses and strains of the swollen Qu'Appelle, we found white baneberry in bloom. We wondered when the llower stem grew thick and red, to hold the showy white berries with the bright black eyes, if the beavers felt their gaze.

One bright day we hailed a distinguished company resting on a burnt-over field. The black field, the checkered white and black backs, hundreds of black-bellied plovers, a picture and pattern to thrill the eye of any viewer.

We did not go to see the Queen, but in July's ravine we saw a royal sight by the duck pond: colonies of anemones - "a host in tine sunshine, a snowdrift in June." Greek legend tells us anemones grew from the tears of Venus shed in the forest over the tragic death of her sweetheart Adonis. Delicate charming tears they must have been.

(Continued on Page 11) 
The "Blue Jay" is certainly a grand magazine and the items are always of great interest. I look forward to every issue. I do wish that I could write well enough to make a contribution sometimes but have no talent for expressing items on paper. (That is just pure imagination! Let us hear from you next time.-Ed.) My effort lies in keeping food for the birds ready at all times and "preaching" bird conservation to every visitor.

ANNE OLSON, Big River, Sask.

\section{A Farmer Looks at Wildlife}

Mrs. Elizabeth Hubbard of Grenfell, Saskatchewan, has sent us a most interesting article on wildlife conservation, reprinted from "The Agricultural Institute Review," and now published in pamphlet form by The Canadian Wheat Pools. The story was written by E. S. Russenholt, of The Canadian Cooperative Wheat Producers, Ltd., Winnipeg, who has written as an introduction:

"Last fall I visited my own homestead in the Swan River Valley where the Northland meets the Prairies - in Manitoba. The change since I left it in 1914, is almost beyond belief.

"Then the hills, south and west, were heavy with timber, and alive with logging camps. The lowlands were solid bush, broken by long muskegs. Water, knee-deep on the level, delayed haying until August. Clearings, hacked out by axe, fire and ox-power, grew fine gardens and feed grains for home use. Sawmills shipped out trainloads of lumber.

"Now the hills are bare of timber. Logging camps are memories. Rivers flood in spring and wither in summer. Muskegs are dry. Open fields stretch mile on mile. Sawmills are replaced by grain elevators that yearly handle millions of bushels."

Do you wish to learn of the dire mistakes that have been made during this remarkable change? Do you believe that wildlife destruction is an inevitable part of "development"?
What should we do about wildlife in developing the best use of our lands and waters? Do you believe that Conservation is: "The use of all our resources of land and water - for the greatest good of the greatest number of all our people"?

If so, write for a copy of this pamphlet to the Canadian Cooperative Wheat Producers, Ltd., Winnipeg. Every advocate of Conservation should get a copy of "A Farmer Looks at Wildlife."

\section{SUMMER TREASURE \\ (Continued from Page 1)}

But to crown summer's experience we spent an afternoon with some of earth's bright company, a group of Avocets. A hot day, brilliant sunshine, breeze off the water and these dazzling creatures. Their long claretpink necks, vivid blue long legs, black and white wings and white bodies, casually swimming, flying, standing and walking so near to us was too thrilling for words. Arrowheads in waxy white bloom set a scene of beauty. Willets, godwits and sandpipers kept them company in the shallow slough. Song sparrows, kingbirds, redwings and martins quenched their thirst beside us, but all seemed incidental in this tryst with beauty.

"What riches has eternity that it can give away -

Such infinite perfection to just a passing day?"

A highlight for a day? A year? A life time!

We did not travel this summer, we had no need to. Treasure was all about us.

Beside us a floral ladder climbed the poplar trunk, the topmost leaves joining to form a cup for the honey suckle spikes of orange and pink. The nectar in the long slender tubes must be reserved for humming birds only.

In the pasture shooting stars fringed the pool where the cattle slaked their thirst. How well named these little cyclamen relatives are, flame coloured anthers and magenta petals. Was it the moist surroundings that gave the blossoms their spicy cinnamon odour? 